\title{
16 \\ Māori political and economic recognition in a diverse economy
}

\author{
Maria Bargh
}

\section{Introduction}

The relationship between Māori and the state in Aotearoa/New Zealand has been radically reshaped in the past 20 years. In some respects, Māori tribal (iwi) enterprises now have more recognition from the Crown, primarily as economic actors, and more access to decision-making power than they have had since the 1820s, when iwi had complete tino rangatiratanga (sovereignty) in Aotearoa/New Zealand. In particular, many iwi enterprises that have completed Treaty of Waitangi settlements ${ }^{1}$ and have re-established a strong economic base are receiving greater recognition from Crown agencies. The Māori Party, formed in 2004, has been instrumental in assisting the Iwi Chairs' Forum (a national grouping of the leaders of tribal enterprises) access ministers and key policymakers, symbolic of the manner in which economic recognition has also led to forms of political recognition.

In other respects, however, the Crown persists with policies, predominantly neoliberal policies, that continue to restrict and marginalise Māori political and economic organisational forms and rights. In this chapter,

\footnotetext{
1 These are negotiated settlements between Māori and the Crown in part as reparation for Crown breaches of Te Tiriti o Waitangi 1840.
} 
I am defining neoliberal policies as those that include reducing the size of the state, promoting forms of trade that have few barriers to the movement of goods and finance, and are premised on the belief that the market is the best mechanism to regulate all forms of human behaviour as people are predominantly self-maximising and selfish individuals (Bargh 2007).

The situation is not as simple as it may appear, however. There is not simply a group of elite Māori recognised by the Crown as economic actors, indoctrinated in neoliberal thought and a marginalised underclass of Mãori resistance. In this chapter, I examine the multiple roles that Māori enterprises inhabit and suggest that expanding the way these roles are defined assists in avoiding simplistic conceptualisations of Māori enterprises, and Māori, as only either champions or victims of neoliberal policies and practices. I end by suggesting that, in order to avoid assuming neoliberal policies consume all other forms of labour and enterprises in economies, critiques of neoliberal policies and practices must be accompanied by an exploration of those areas of a diverse economy that are forging other alternative neoliberal or non-neoliberal worlds.

\section{Increasing recognition of Māori enterprises and economy}

When considering the topic of 'recognition' it is important to note that Māori hapu and iwi have long been recognised by and recognise the political and legal status and institutions of other hapu and $i w i$, as well as other indigenous nations in the Pacific (Petrie 2006). When considering the recognition of Māori by non-indigenous actors, one of the earliest forms of informal recognition for particularly the northern tribes in New Zealand came in a letter from King William IV in 1832, read out by James Busby, the first appointed British Resident of New Zealand (Waitangi Tribunal 2014). In the letter, King William IV proposed that, in exchange for Mãori protecting the British Resident, they would receive benefits from the 'friendship and alliance with Great Britain' (Waitangi Tribunal 2014: 114). Formal recognition of Māori sovereignty came in the 1835 Declaration of Independence and Te Tiriti o Waitangi 1840 (Mutu 2010). 
In the subsequent century and a half after 1840 , the Crown breached Te Tiriti o Waitangi in a variety of ways through their actions and inaction. Māori used numerous political and legal avenues in attempts to have these breaches rectified, and eventually in the 1970s significant progress was achieved with the establishment of the Waitangi Tribunal to hear cases brought by Māori about Treaty breaches. The Crown also established a direct negotiations process in the mid-1990s to ensure further control over the process and to speed up the 'full and final' settlements of historical Treaty breaches (Durie 1999).

The Crown's Treaty of Waitangi settlement process has led a number of government agencies to pay close attention to the governance structures of iwi enterprises. Two agencies have a significant role in the assessment and structuring of $i w i$ governance structures. The first is the Office of Treaty Settlements (OTS), which is based within the Ministry of Justice and takes a leading role in direct negotiations on behalf of the Crown. The second is the Māori Fisheries Commission (Te Ohu Kaimoana), which was created originally by the Treaty of Waitangi (Fisheries Claims) Settlement Act 1992 and modified with the Mãori Fisheries Act 2004. ${ }^{2}$ In particular, the OTS and Te Ohu Kaimoana have sought to ensure that iwi enterprises have governance structures that they view as appropriate to manage returned financial and commercial assets. Those enterprises recognised and deemed appropriate to the Crown are commonly referred to as 'post-settlement governance entities' and those recognised by Te Ohu Kaimoana as 'mandated iwi organisations'. Post-settlement governance entities and mandated iwi organisations follow specific processes relating to mandating, representation, governance and accountability that are prescribed by the OTS and Te Ohu Kaimoana (OTS 2015, Te Ohu Kaimoana n.d.). Those enterprises that follow these prescriptions are subsequently formally recognised by the Crown (Cowie 2012). Those iwi enterprises that do not follow these prescriptions do not receive recognition, as was the experience in 1998, for example, when the iwi of Whakatohea declined their settlement (Graham 1998, Vertongen 2012). The Waitangi Tribunal has reported other occasions where iwi groups have been excluded from negotiations because the OTS picked other 'favourites' (Waitangi Tribunal 2007).

2 For the full text of the Treaty of Waitangi (Fisheries Claims) Settlement Act 1992, see www. legislation.govt.nz/act/public/1992/0121/latest/DLM281433.html. For the full text of the Mãori Fisheries Act 2004, see www.legislation.govt.nz/act/public/2004/0078/latest/DLM311464.html. 
Around 50 iwi have had legislation pass through parliament to bring their Deeds of Settlement with the Crown into effect. This is an ever-changing figure, as new settlements are reached and other settlements relating to specific resources (such as rivers) are additional to this number. At least 10 of the post-settlement governance entities resulting from these 50 settlements have been operating for more than 10 years, including the two financially largest settlements of Ngāi Tahu and Waikato-Tainui.

Crown and Māori attention has turned therefore to not only recognising but also to assessing the performance and activities of the post-settlement governance entities, and there has been a proliferation of theses and government, scholarly and popular reports about the potential of Māori enterprises and the 'Māori economy' (Mataira 2000, Warriner 2009, Hudson 2014, Spiller et al. 2015, Prendergast-Tarena 2015).

In 2003, a report commissioned by Te Puni Kōkiri (the Ministry of Māori Development), Mãori economic development, encouraged government and readers in general to consider the Māori economy in new ways, as full of potential and a success rather than as a drain on the New Zealand economy. The report argued further that Māori culture was a significant feature of the Mãori economy and could support the profitability and success of Māori businesses (NZIER 2003). Subsequent media coverage about the report encouraged the general public to consider a similar re-evaluation (James 2003).

In 2009, the Māori Economic Taskforce was established by the Minister of Māori Affairs to provide:

opportunities for Māori to contribute to and benefit from a thriving New Zealand economy. It seeks to enhance Māori entrepreneurship and innovation to position Māori for future strategic economic opportunities and promote kaupapa Māori and Mãori structures as drivers of prosperity (Te Puni Kōkiri 2010).

The Taskforce contracted Business and Economic Research Ltd (BERL) to conduct a number of reports around the Māori economy, and, in the more general media, BERL promoted and marked the change in the way that the Māori economy was being described in New Zealand. One article in 2010 described the Māori economy as a 'sleeping giant' and argued that 'the Māori economy is an integral part of the New Zealand economy and spans several industries' (BERL 2010). 
Most importantly, the 2010 BERL article highlighted the recognition of the Māori economy, and suggested that Māori people were adding economic value to the New Zealand economy. Clearly there are many ways Māori had been contributing to New Zealand earlier alongside the economic contribution-but the fact that the economic contribution aroused so much interest is indicative of the level to which neoliberal policies and practices have permeated the New Zealand Government and government-related research.

Te Puni Kōkiri has also partnered with the Federation of Mãori Authorities, which represents iwi and Māori landowners and regional councils to commission 'Māori economy' reports for their regions (Te Puni Kōkiri 2013, 2014). In Auckland, the Independent Māori Statutory Board commissioned research from the New Zealand Institute of Economic Research (NZIER) for a similar report for the Auckland region (NZIER 2015). These commissioned reports have a dual function. For the iwi organisations, they provide statistics to support their own awareness of the nature of their business and to communicate that position to their people. The second function of these reports is for the iwi to use in communication with external entities to raise awareness in the broader non-Māori community of the existence of the Mãori economy. In this latter regard, iwi are seeking recognition from local government, local businesses, central government and national businesses of the contribution that Māori make to economies, and to encourage them to therefore be more attentive to Māori concerns and rights.

Alongside an increasing recognition and quantification of the Māori economy asset base has been a parallel Mãori conversation about the need for Māori to balance the articulation of their economic nature and success with their Mãori nature and success for Māori. The idea of bringing together Māori ways of doing things with those of non-Māori, whether it be in the areas of, for example, business or research, is not a new phenomenon and has been regularly discussed by Mãori since non-Māori arrived in New Zealand. Māori leader and politician of the early 19th century Apirana Ngata instructed Māori to maintain a balance between acquiring the tools of Europeans (Pākehā) and protecting the treasures of Māori, and is commonly quoted by Māori scholars (Mahuika 2008). The combining of dual cultural and legal values and practices has been used by many Māori in an attempt to retain land and maintain levels of self-determination in response to colonisation (Durie 1999). 
This combining of dual cultural and legal values and practices in response to colonisation has resonance with Māori strategies in the context of a 'neoliberal age'. When some Māori began using phrases such as 'corporate warriors' in the 1980s, it was reflecting the sense of a need to link Māori values with the increasingly common neoliberal policies and practices that the government was encouraging, including in their interactions with Māori (Bargh 2007). As O'Sullivan also noted in Chapter 13 of this volume, some Māori also saw potential in the neoliberal rhetoric of 'empowerment' to support their self-determination aspirations (Bargh 2007). Some Māori continue to see potential in connecting neoliberal policies that value particular forms of economic entrepreneurship and Māori political and economic aspirations (Keelan \& Woods 2006).

\section{Political recognition}

The greater recognition of Māori economic entities has been accompanied by forms of greater political recognition, much of which has been channelled by the Māori Party. After the 2008 general election, the National Party entered a Relationship Accord and Confidence and Supply Agreement with the Māori Party. This agreement has enabled a number of channels for political conversations between not just the two political parties, but also some of their key supporters. In the case of the Māori party, some of those key supporters are economically larger iwi enterprises, which have a clear agenda for the return of particular natural resources and most of which want to advance their cultural, environmental, political and economic aspirations. ${ }^{3}$ In their chapters of this volume, O'Sullivan (Chapter 13) and Humpage (Chapter 14) detail examples of some of the social policy aspirations. To a certain extent, therefore, forms of economic recognition are helping to produce some forms of political recognition for $i w i$. One way of interpreting this is that economically powerful Mãori are seen to have acquired the necessary skills to be more capable of governing their own affairs (Bargh 2011).

It is worth noting that those iwi that do receive political recognition constitute a small group of the total number of iwi and are primarily those that attend the Iwi Chairs' Forum. The Iwi Chairs' Forum was first convened in 2005 with around five established iwi. The numbers of iwi attending has increased substantially, and subcommittees work

3 For more information, see the Iwi Chairs' Forum website: iwichairs.maori.nz/. 
between meetings on select issues of importance (Te Aho 2014). Those iwi representatives working on select issues have access to government ministers and officials. For some issues, such as freshwater management, for example, the Iwi Chairs' Forum also has 'technicians' and 'iwi leaders' on Ministry for the Environment internal water allocation policy groups, and on the government-established Land and Water Forum to advise government officials (Te Aho 2014).

The challenge that accompanies this dynamic - a small group with influence-is that the lines of transparency and accountability are not always clear. Lawyer Annette Sykes spoke on this topic in her 2011 Bruce Jesson lecture, where she criticised the Iwi Chairs' Forum and requested greater transparency regarding the mandate of particular officials and decision-making processes within the forum. Sykes' broader concern was that these forms of decision-making were neoliberal in nature and practice. She argued that, seen in this context, 'the newly constructed layer of Māori leadership seems to be a quango which the Crown then resources as part of its specific consultation requirements in the expectation it will generate an acceptable Māori view’ (Sykes 2011).

She argued further that the Iwi Chairs' Forum was using achievements by Māori in the areas of education, language and the political and legal struggle regarding ownership of the foreshore and seabed for narrow neoliberal aims.

The NICF [National Iwi Chairs' Forum] has capitalised on that momentum for change. Surfing on the tide of discontent they have assumed the space that grass roots activists created, and promoted neo liberal goals, such as the right to exploit the vast natural resources under the sea, that are more in keeping with capitalism than with the tino rangatiratanga that was being called for (Sykes 2011: n.p.).

Sykes provided the example of government consultation on the Emissions Trading Scheme to illustrate her point that a small group of Māori who alone have access to information, without broader Māori or public discussion and scrutiny, is prone to being captured by advocates of neoliberal policies.

Similar processes have been evident in 2015 and 2016, with consultation between the government and the Iwi Chairs' Forum on water ownership and allocation models. The options being proposed by the government and now considered by the Iwi Chairs' Forum are primarily options 
for the marketisation of the water allocation regime (Ministry for the Environment 2016). Non-neoliberal options that involve water being cooperatively managed by guardians, who might also manage, say, plant restoration projects, are considered and advocated by iwi at regional meetings but do not result in a change in government policies (Te Aho 2014).

\section{Multiple roles in a diverse economy}

There is plenty to be concerned about when it comes to the persuasive and pervasive nature of neoliberal policies and practices. The extension of the market mechanism to govern areas previously governed in other ways has resulted in breaches of Māori rights in the areas of water management, Māori land management and resource exploitation (Bargh 2016). Sykes' perspective on the interaction between the Iwi Chairs' Forum and the Crown suggests a Māori elite co-opted by neoliberal policies and practices. However, it would be counter-productive to assume that all Māori actions can be reduced to sit within a neoliberal framework. Māori, like other peoples, inhabit multiple roles in the economy and are employing multiple strategies simultaneously. Māori are 'economic actors with multiple roles' (Gibson-Graham et al. 2013: xx).

The continued prevalence of neoliberal policies in many countries has led some scholars within groups on the left to analyse the way leftist analysis tends to operate. In her article 'Resisting Left Melancholy', for example, Wendy Brown argues that traditional leftist analyses and politics are too rigid and no longer provide a compelling vision or strategy for another 'order of things' (Brown 1999: 25). Similarly, JK Gibson-Graham (2006) has written extensively on the role that emotions play in leftist critique and has argued that negativity and pessimism within leftist thinkers has often produced paralysis. The relevance of their argument here is their insistence that, instead of being fixated on a particular form of power from which leftists are excluded, a more productive orientation is to look for the places where people and communities are already engaged in multiple roles with multiple possibilities for political and economic transformation (Gibson-Graham 2006). Scholars like JK Gibson-Graham argue that when scholars and communities focus on the diverse nature of the economy and the multiple roles people have, it extends a vision of where change can occur: 'small actions can initiate major changes' (Gibson-Graham et al. 2013: xxiii). 
If the Iwi Chair's Forum is taken as a focus point from which to consider the diverse economy framework, a wide range of activities become apparent that are not simply neoliberal but that promote labour, enterprises, transactions, property and finance that are non-capitalist or alternative capitalist. For example, if the Waikato River Settlement and associated iwi enterprises are taken as an illustration, there are numerous associated activities that are other than just neoliberal practices. Representatives from the Waikato iwi participate in the Iwi Chairs' Forum and were responsible for negotiating the Waikato River Settlement that created five River Trusts for $i w i$, with tributaries flowing into the Waikato River. ${ }^{4}$ One of these is the Te Arawa River Iwi Trust, which has funded projects for riparian planting of waterways, investigating and building a microhydroelectric dam and the restoration of native freshwater species (George 2016). Within each of those projects, iwi members have been involved in paid labour, voluntary work and other forms of labour. The microhydroelectric project has led to the building of a native nursery, for which seeds have been eco-sourced from the tribe's forest and research (paid and voluntary) into the feasibility of a glasshouse for restoration of native fresh water species has begun. It has generated non-market transactions: gift and cultural exchanges.

Another example of an enterprise that is involved with the Iwi Chairs' Forum and a multiplicity of other activities is the Te Arawa Lakes Trust. Formed after the 2006 Te Arawa Lakes Settlement between the Crown and Te Arawa tribe, it returns ownership of the beds of a number of lakes in the Bay of Plenty area to Te Arawa, along with a dedicated role in the management of the lakes. ${ }^{5}$ The Trust aims to increase the financial asset base of the organisation alongside supporting people into training and promoting a cultural values framework about the lakes. In 2015, the Trust provided its membership list to enable the Rotorua District Council to establish a Te Arawa Partnership Board for the iwi to contribute directly to local government decision-making (Te Arawa Lakes Trust 2015). Therefore, while there is limited transparency about the exact nature of the discussions that Te Arawa Lake Trust representatives participate in at the Iwi Chairs' Forum and with government ministers, it would be far too simplistic to label the organisation as just promoters of neoliberal policies (see Table 16.1).

4 For the full text of the Waikato-Tainui Raupatu Claims (Waikato River) Settlement Act 2010, see www.legislation.govt.nz/act/public/2010/0024/latest/DLM1630002.html.

5 For the full text of the Te Arawa Lakes Settlement Act 2006, see www.legislation.govt.nz/act/ public/2006/0043/latest/DLM381398.html. 
THE NEOLIBERAL STATE, RECOGNITION AND INDIGENOUS RIGHTS

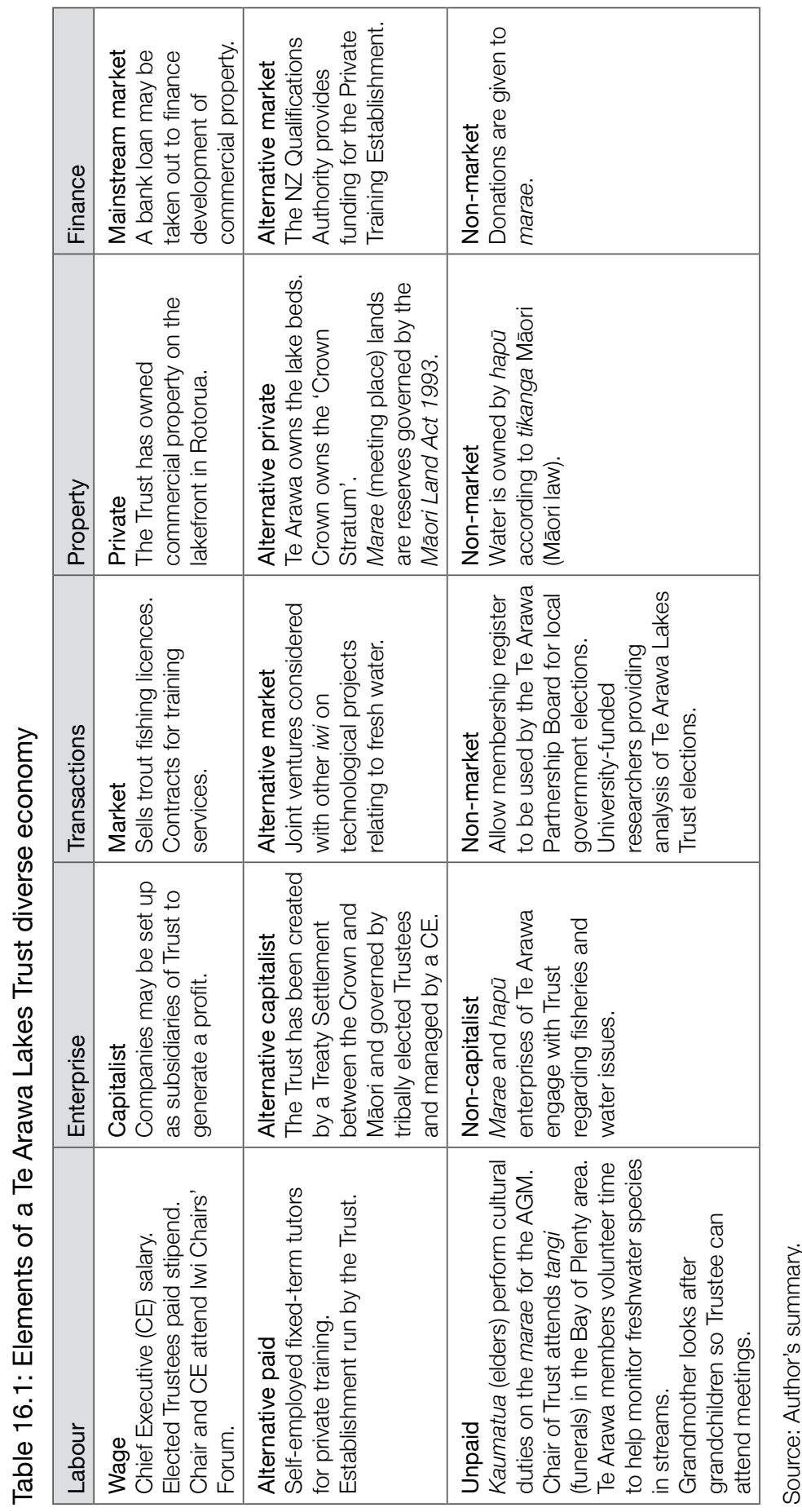


When Julie Graham and Katherine Gibson began creating the diverse economies framework, one of the challenges that emerged came from other leftist thinkers who argued that simply creating inventories of diverse practices was at best not going to work and at worst going to result in complicity with global capitalism (Gibson-Graham 2006). To consider that challenge in the context of Māori enterprises, one way of clarifying that highlighting new possibilities and activities aims to support the proliferation of 'another possible world' is to also highlight those entities that are comprised more of non-capitalist and non-market elements. Due to limitations on space in this chapter, I would like to mention two examples with different forms to give a sense of the range that exist for Mãori. The first example comes from Ngāi Tühoe, who in their settlement with the Crown in the Te Urewera Act 2014 insisted on creating legal personhood for their traditional mountain Te Urewera. Tūhoe have also built Te Kura Whare, a living building, at Taneatua that utilises renewable energy and other sustainable practices. ${ }^{6}$ The second example is the Tuaropaki Power company, which is owned by the Tuaropaki Trust, a Mãori Land Trust that generates electricity with a geothermal power station and has established a milk-processing factory, temperature-controlled horticulture and worm farm to support sustainable environmental practices. ${ }^{7}$

Maliha Safri and Julie Graham argue that if you change the way you identify and speak about the economy, you create a new imagining of possibilities. In their article about the global household, they argue that household production can 'account for as much as half of world economic activity (depending on the accounting system being employed)' (Safri \& Graham 2010: 104). That kind of image redefines who would be considered the most significant actors. Similarly, creating an inventory of who is involved in the diverse economy of Mãori rights and recognition creates a much more complex picture of alternative and non-capitalist aspects. Using a language of economy that includes these multiple activities assists in making them more visible and bring them further into reality.

6 For more information, see the Ngāi Tūhoe website: www.ngaituhoe.iwi.nz/sustainability-andthe-living-building-challenge.

7 For more information, see the Tuaropaki website: tuaropaki.com/. 


\section{Conclusion}

Many aspects of the relationship between Māori and the Crown have changed markedly in New Zealand. In large part, this has been influenced by neoliberal policies that value economic relationships. Many iwi have engaged in the Crown's Treaty of Waitangi settlement process for recognition and compensation for breaches of Te Tiriti o Waitangi and have established new governance entities as a result. Post-settlement governance entities generally fit within the parameters of forms of organisation the Crown finds acceptable, arguably reflecting more longstanding traditions of imperial recognition of cultural difference that it finds appropriate (Buchan 2008). Many of those post-settlement governance entities seek solidarity, cooperation and political leverage through the Iwi Chairs' Forum. The operations and decision-making processes of the Iwi Chairs' Forum are not particularly transparent and have led to criticism that the forum functions to support neoliberal policies and practices.

However, that is not all post-settlement governance entities or iwi enterprises are. Closer examination suggests that many of the activities of the iwi entities that participate in the forum contain non-neoliberal and alternative neoliberal aspects, and a much more diverse economy becomes apparent. In order to sustain hope that there are possibilities outside a 'neoliberal age', an identification and critique of neoliberal policies and practices must be accompanied by an elaboration of the multiple roles that enterprises and peoples also play in a diverse economy.

\section{References}

Bargh M (2007). Mãori development. In Bargh M (ed.), Resistance: An indigenous response to neoliberalism, Huia, Wellington.

Bargh M (2011). Moving on from a developmental view of humanity. Alternatives 36(1):79-85, doi.org/10.1177/0304375411402022

Bargh M (2016). Alternative energy and economics. Paper presented at In the Eye of the Storm: Pacific Climate Change Conference, Victoria University of Wellington, 17 February.

BERL (Business and Economic Research Limited) (2010). The Mãori economy —A sleeping giant about to awaken? 22 December, berl.co.nz. 
Brown W (1999). Resisting left melancholy. Boundary 2 26(3):19-27.

Buchan B (2008). Asia and the moral geography of European enlightenment political thought 1600-1800. In Nederman C and Shogimen T (eds), Western political thought in dialogue with Asia, Lexington Books, Lanham.

Cowie D (2012). The Treaty settlement process. In Wheen N and Hayward J (eds), Treaty of Waitangi settlements, Bridget Williams Books, Wellington, doi.org/10.7810/9781927131381_3.

Durie M (1999). Te mana te kawanatanga: The politics of Māori self-determination, Oxford University Press, Oxford.

George K (2016). Iwi environmental management plan, Te Rünanga o Ngäti Keal Ngāti Tuara, Rotorua.

Gibson-Graham JK (2006). A post capitalist politics, University of Minnesota Press, Minnesota.

Gibson-Graham JK, Cameron J \& Healy S (2013). Take back the economy, University of Minnesota Press, Minneapolis, doi.org/10.5749/minnesota/ 9780816676064.001 .0001 .

Graham D (1998). Whakatohea Deed of Settlement to be terminated, media release, Wellington, 13 March, www.beehive.govt.nz/release/whakatoheadeed-settlement-be-terminated.

Hudson JT (2014). Te Paewai o te Rangi: A framework for measuring iwi outcomes. PhD thesis. Massey University, Albany.

James C (2003). Revising stereotypes of Māori economy. New Zealand Herald, 3 February, www.nzherald.co.nz/business/news/article.cfm?c_id=3\&objectid $=3099282$.

Keelan J \& Woods C (2006). Mauipreneur: Understanding Māori entrepreneurship, International Indigenous Entrepreneurship, Advancement, Strategy and Education, www.indigenousjournal.com/IIJEASVolIIIss1 Woods.pdf.

Mahuika R (2008). Kaupapa Māori theory is critical and anti-colonial. MAI Review 3.

Mataira JP (2000). Ngā kai arahi tuitui Māori: Māori entrepreneurship: The articulation of leadership and the dual constituency arrangements associated with Māori enterprise in a capitalist economy. PhD thesis. Massey University Albany, Auckland. 
Ministry for the Environment (2016). Fresh water: Allocation work programme, Cabinet paper, Wellington, www.mfe.govt.nz/sites/default/files/media/Fresh \%20water/Freshwater\%20Allocation\%20Work\%20Programme $\% 20 \% 20$ Terms\%20of\%20Reference\%20and\%20Appointmen....pdf.

Mutu, M (2010). Constitutional intentions: The Treaty of Waitangi texts. In Mulholland M and Tawhai V (eds), Weeping waters: The Treaty of Waitangi and constitutional change, Huia Publishers, Wellington.

NZIER (New Zealand Institute of Economic Research) (2003). Mãori economic development: Te öhanga whanaketanga Māori, NZIER, Wellington.

NZIER (2015). The Auckland Mãori economy report: Sizes, issues and opportunities, nzier.org.nz/publication/the-auckland-m\%C4\%81ori-economy.

OTS (Office of Treaty Settlement) (2015). Healing the past: Building a future, www.govt.nz/assets/Documents/Red-Book-Healing-the-past-building-afuture.pdf.

Petrie H (2006). Chiefs of industry. Auckland University Press, Auckland.

Prendergast-Tarena ER (2015). Indigenising the corporation: Indigenous organisation design: An analysis of their design, features, and the influence of indigenous cultural values. PhD thesis. University of Canterbury, Christchurch.

Safri M \& Graham J (2010). The global household: Toward a feminist postcapitalist international political economy. Signs 36(1):99-125, doi.org/ $10.1086 / 652913$.

Spiller C, Barclay-Kerr H \& Panoho J (2015). Wayfinding leadership: Groundbreaking wisdom for developing leaders, Huia, Wellington.

Sykes A (2011). Bruce Jesson memorial lecture, 5 July, Auckland, www.brucejesson. com/annette-sykes-2010-bruce-jesson-memorial-lecture/.

Te Aho L (2014). Report to the Iwi Advisory Group from the Freshwater Iwi Leadership Regional Hui, iwichairs.maori.nz/wp-content/uploads/2015/06/ Waimaori-Report-IAG-Hui-2014-revised-5.12.14.pdf.

Te Arawa Lakes Trust (2015). Te Arawa Lakes Trust annual report 2014/2015, www.tearawa.iwi.nz/files/te_arawa_iwi/keydocuments/TALT\%20Annual \%20Report\%202014-2015.pdf.

Te Ohu Kaimoana (n.d.). Mandating process, teohu.maori.nz/iwi/mandate_ process/flowchartFLASH.swf. 
Te Puni Kōkiri (2010). Annual report for the year ended 30 June 2010, www.tpk. govt.nz/mi/a-matou-mohiotanga/corporate-documents/annual-report-forthe-year-ended-30-june-2010/online/13.

Te Puni Kōkiri (2013). Māori economic development strategy, www.bayof connections.com/downloads/BOC\%20MAORI\%20ECONOMIC\%20 Strategy\%202013.pdf.

Te Puni Kōkiri (2014). Māori economy in the Waikato Region, www.tpk.govt.nz/ en/a-matou-mohiotanga/business-and-economics/maori-economy-in-thewaikato-region.

Vertongen B (2012). Legal challenges to the Treaty Settlement process. In Wheen $\mathrm{N}$ and Hayward J (eds), Treaty of Waitangi Settlements, Bridget Williams Books, Wellington, doi.org/10.7810/9781927131381_4.

Waitangi Tribunal (2007). Final report on the impacts of the Crown Treaty Settlement policies on Te Arawa Waka and other tribes, Legislation Direct, Wellington.

Waitangi Tribunal (2014). Te Paparahi o Te Raki: Northland inquiry part one, Legislation Direct, Wellington.

Warriner V (2009). Internationalisation of Māori businesses in the creative industry sector. PhD thesis, Massey University, Auckland. 
This text is taken from The Neoliberal State, Recognition and Indigenous Rights: New paternalism to new imaginings, edited by Deirdre Howard-Wagner, Maria Bargh and Isabel AltamiranoJiménez, published 2018 by ANU Press, The Australian National University, Canberra, Australia.

doi.org/10.22459/CAEPR40.07.2018.16 